\title{
THE NATURE AND SIGNIFICANCE OF THE TERMS IN THE CONTRACTUAL OBLIGATIONS
}

\section{Guyvan P. D.}

\section{INTRODUCTION}

The contract is one of the main elements of the rule of law, which legally ensures the validity of exchange processes in order to meet the needs of society as a whole, individual citizens or their associations ${ }^{1}$. Almost a third of the civil law rules on the legal regulation of contractual obligations, to some extent, there is an indication of the time of implementation of their rights and obligations. The concept of contract is enshrined in Part 1 of Art. 626 Civil code of Ukraine (CCU). It is an agreement between two or more parties aimed at establishing, changing or terminating civil rights and obligations. Thus, as we see, the legislator in this definition gives the contract the meaning of the transaction. Indeed, the conclusion of a contract is a kind of ways of emergence of subjective rights and obligations (Article 11 of the $\mathrm{CCU}$ ), and in this context it is one of the transactions that as a legal fact entail the occurrence of these legal consequences. However, the doctrine has long emphasized the two-dimensional legal meaning of the concept of "contract". In addition to the definition described above, the contract also has something that determines the content of specific subjective rights and legal obligations of the counterparties. In this sense, the contract is a means of regulating the behavior of the parties in civil law. Moreover, given the dispositive nature of civil relations in the contractual sphere, the law is pushed to the second place, preferring the contract ${ }^{2}$.

The structure of the contract consists of obligations. That is, such a relationship in which one party (the debtor) must perform in favor of the other party (creditor or creditor) a certain action or refrain from a certain action, and the creditor has the right to require the debtor to perform his duty (Part 1 of Article $509 \mathrm{CCU}$ ). Most contracts have several binding relationships between the parties, and they are reciprocal. In other words, a creditor for one contractual obligation is also a debtor for another, as is a debtor. For example, in a property lease agreement, the lessee is the creditor under the obligation to transfer the thing, so he has the right to require the landlord, who is considered the debtor, to fulfill his obligation and transfer the thing for temporary use. Instead, for a

1 Кузнєцова Н.С. Подрядные договоры в инвестиционной деятельности в строительстве. Киев : Наукова думка, 1993. С. 41.

2 Ромовська 3.В. Проблема загальної теорії права у проекті ЦК України // Кодифікація приватного (цивільного) права України / За ред. А. Довгерта. Київ, 2000. C. 42. 
monetary obligation, which is also necessarily included in the content of this agreement, the roles of the counterparties change to the opposite: the debtor is already the tenant. He must therefore fulfill his obligation to pay for the use of the property to the landlord, who, being the creditor in this interaction, has the right to demand the said funds.

\section{Temporal dimensions of civil obligation}

One of the main principles of modern property turnover is the principle of proper performance of obligations ${ }^{3}$, the essence of which is that performance should be carried out by the parties properly in accordance with the terms of the contract and the law, and in the absence of such conditions and requirements - in accordance with business customs. turnover or other requirements that usually apply (Article 526 of the CCU, Part 1 of Article 193 of the Economical (Commercial) code of Ukraine (CCU). It is as a result of proper performance that the interests of the creditor are most satisfied. The attribute of performance of the obligation under the contract is the parties, term and place of performance. One of the important elements of this principle is that the rule regarding the properness of performance also applies to the timeliness of actions that constitute the content of the obligation. In particular, in Art. 530 of the CCU indicates: 1) if the obligation sets a deadline for its implementation, it is subject to performance within this period (deadline). An obligation, the term of which is determined by an indication of an event that is inevitable to occur, is subject to fulfillment with the occurrence of this event. 2) if the term of the debtor's performance of the obligation is not established or determined at the moment of filing the claim, the creditor has the right to demand its performance at any time. The debtor must perform such an obligation within seven days from the date of the claim, if the obligation of immediate performance does not follow from the contract or acts of civil law.

We will give a more detailed description of the rule of the given norm. Indeed, the question of the terms of fulfillment of the obligation by the counterparty under the contract is extremely important. After all, the possibility of further realization by the creditor (creditor) of his subjective right depends on the determination of the moment from which the debtor's obligation to perform a certain obligation arises and the moment at which such obligation ends, ie the establishment of the term of performance of the obligation. and, finally, the possibility of his judicial protection. The legal content of the legal relationship is the subjective rights and obligations of its participants. At the same time, it is indisputable that rights and obligations exist throughout the life of the legal relationship, because, assuming the opposite, we inevitably come to the

${ }^{3}$ Beatson J., Burrows A., Cartwright J. Anson's Law of Contract/ $27^{\text {th }}$ ed. Oxford ; New York, 1998. P. 7-8. 
conclusion about the possibility of the existence of meaningless phenomena ${ }^{4}$. It is during the course of its existence that the rights and obligations that constitute the content of civil relations are exercised. During the term of subjective civil law, a person may exercise the powers inherent in its content by either performing certain actions independently, or requiring adequate actions from other persons. In case of non-exercise of his subjective substantive right in time as a result of the guilty act of the debtor, a protective legal relationship of protective content arises.

The protection of subjective civil law, as follows from the analysis conducted in the previous sections of this work, in the temporal sense is possible only after the violation of such a right. Therefore, it cannot be considered a breach of a duty that has not yet occurred. For commitments that have a deadline, everything is quite simple and the determination of the moment of its delay does not require additional comments. It is more difficult to determine the duration of the obligation to be fulfilled after the creditor's request, as the initial term of the regulatory relationship is not obvious. It is obvious that the violation of the creditor's right can occur only after such a claim, but, of course, not immediately. The fact is that the creditor's claim can be made when he wants, even if it happened, for example, ten years after the conclusion of the contract. This requirement first gives effect to the regulatory legal relationship, the debtor receives a so-called "grace period" to perform the duty. As a general rule, this period is seven days, however, a special rule or agreement of the parties may set a different duration.

It should be borne in mind that Ukrainian civil law actively operates with such concepts as "reasonable time" and "business practice". The problem of fulfillment of the obligation under the uncertainty of the term under study is perhaps the most related to these terms, because some civil relations are characterized by such periods of performance of duties, which are governed primarily by reasonableness and business practice. For example, take a storage contract that does not specify the duration of the relationship. Here, the term of delivery of property at the request of the bailor, depending on its type and nature of storage is often regulated by these "quasi-legal" categories. Therefore, it would be appropriate in the text of Part 2 of Article 530 of the Civil Code to make reference to such regulators as well.

Thus, the obligation to fulfill comes after the creditor submits the claim and must be fulfilled immediately, within seven days or within the period established by special rules after the claim. When can a creditor make such a claim? To do this, it is necessary to clearly understand what exactly are the obligations under which the term (term) of performance is not determined or determined at the time of the creditor's claim and what is the practical form of specific agreements in the presence of such obligations. Agreements that do not specify the term or term of the debtor's performance do not specify

\footnotetext{
${ }^{4}$ Иоффе О.С. Гражданское право. Избранные труды. Москва : Статут, 2000. C. 666 .
} 
the possibility of a future creditor's claim. This may be the obligation of the lessee to return the property under the lease agreement, the obligation of the borrower under the loan agreement, the duty of the custodian under the storage agreement (Part 2 of Article 938 of the Civil Code of Ukraine), etc. If the term of performance is not specified and there is no mention in the contract of a possible claim of the creditor, such a claim may still be presented to the debtor at any time after the conclusion of the contract. This, in turn, necessitates the performance of a contractual obligation. When concluding an agreement, in which the term of performance is determined at the time of filing the claim, its text must contain a reservation on the need to fulfill the obligation by the debtor after the creditor declares such a claim.

However, the stylistic analysis of the legal norm of Part 2 of Art. 530 of the Civil Code of Ukraine shows that it does not refer to any specific deadline for filing a claim. It is a matter of fulfilling the duty when the claim is made. However, it follows from the content of the norm that the statement of claim can take place at any time after the conclusion of the contract. That is, the consequences of the fulfillment of the obligation, when its term is determined by the moment of filing the claim, and the consequences of the fulfillment of the obligation, the term of which is not set, are almost the same. With few exceptions. The first of them is the various legal consequences established by law. In other words, for some relationships there are again special legal rules that govern these cases differently. Thus, Part 3 of Article 938 of the Civil Code of Ukraine provides for additional legal consequences for the custodian of the property if the period of storage of the thing is determined by the time of the pledgor's claim for its return. In this case, in contrast to the same contract, but concluded without a storage period, the custodian has the right with the expiration of the usual storage period in these circumstances to require the bailor to pick up the thing within a reasonable time. In our opinion, such an exception partially coincides with the second exception, which will be described below, but only under one condition: if the term of performance of the obligation is not determined by any moment of the creditor's claim against the debtor (at his discretion), and determined by a certain time for filing a claim, which does not coincide with the conclusion of the contract and will have a specified initial (and possibly final) term in the future.

Thus, the design of Part 2 of Art. 530 of the CCU covers both of the following cases: a) filing a claim for enforcement at any time at the discretion of the creditor; (b) making such a request from a specified date in the future. Despite the almost identical legal consequences of their application, we must emphasize that the legal regulation of such relations is somewhat different. In the first case, it is identical to the legal regulation of obligations, the term of which is not set: the right to make a claim begins with the creditor from the time of the contract and he can exercise it at any time. In the second case, the right to file a claim against the debtor for the performance of the obligation arises from a certain specified date after the conclusion of the contract and can 
also be exercised at any time. If the contract or law establishes not only the beginning of the term for the creditor's claim against the debtor, but also the term of its expiration, the creditor may demand performance from the debtor within this period, outside - before and after its expiration - the creditor does not have such a right.

In general, Chapter 48 of the Civil Code is structured in such a way as to establish rules of conduct for counterparties that meet the definition of "proper performance of an obligation". All actions that are outside the scope of these rules should be considered improper performance of duties. Similarly, Part 2 of Article 530 of the CCU was constructed and commented on. It establishes a mechanism for lawful actions of the debtor under the obligation, the term of which is not defined or determined by the time of the claim: he must perform the obligation within seven days from the date of the claim, if the obligation of immediate performance does not follow from the contract or civil acts. legislation. Under this rule, the regulatory obligation to perform begins at the request of the creditor and terminates after seven days. And only the nonfulfilment of such an obligation leads to the improper fulfilment of the obligation, which occurs in this case in the form of overdue debt.

The fact that the creditor's right is not considered violated and the debtor's obligation is not overdue (not performed properly) in case the creditor fails to file a claim clearly follows from Part 2 of Article 530 of the Civil Code of Ukraine. In accounting, such a liability should be recorded as a debt obligation with a maturity that has not yet come. Of course, any security requirements related to non-compliance cannot be imposed yet. This combines the investigated obligations with an indefinite term of performance with the obligations to be fulfilled after the occurrence of a specific phenomenon: in both cases before a certain moment or event (creditor's request or navigation) the fulfilment of such an obligation is not mandatory, and voluntary performance should be considered as early provided that there are grounds under Art. 531 of the Civil Code of Ukraine. However, there are some differences between the investigated commitments and the deferred commitments. For the latter, after the expiration of the term, the obligation should be considered overdue, and the civil right of the creditor - violated. From this point on, the protection relationship begins, so the person can go to court to protect his or her subjective right. Analyzing the obligations with an indefinite term of performance or due to the creditor's claim, it should be noted again that before the creditor's claim cannot be considered his subjective right violated, and therefore one that can be defended in court.

In the literature there are comparisons of the commented contractual relations with indefinite term of performance of an obligation with those in which legal consequences are connected with occurrence of a postponement circumstance (item 212 of $\mathrm{CCU})^{5}$. If the obligation is entered into with a suspensive condition, the rights and obligations of the parties to the relationship arise after the

${ }^{5}$ Raiser L. Dinglishe Anwartschaften. Tubingen, 1961. S. 3-4. 
occurrence of this condition ${ }^{6}$. Accordingly, a violation of a subjective right can occur only after that. Indeed, deferred and indefinite obligations, when the commencement of performance depends on the filing of a claim, have some similarities in the legal results of their occurrence ${ }^{7}$. In both cases, the legal relationship of the stipulated content does not arise immediately, its beginning is postponed until a certain action of the creditor or the occurrence of some circumstance. However, there are some differences between these two phenomena that do not allow to identify them. The occurrence of an indefinite period (submission of a regulatory requirement by the creditor) gives rise not to the obligation itself, but only to the obligation to fulfill it. Therefore, the debtor's early performance of his duty will be appropriate. Instead, the onset of a suspensive circumstance leads to the formation of the content of the legal relationship, giving it an impetus for possible implementation. Therefore, early enforcement under these conditions cannot be considered appropriate given the lack of legal grounds for it.

Additional difficulties of theoretical and practical nature arise when the ability of the creditor to file a claim is limited to a certain period. For example, the counterparties have entered into a loan agreement under which the repayment of the debt will take place at the request of the creditor, which he must present no later than two years. The possibility of filing accounts payable, which would trigger the entry into force of the regulatory relationship, in this case is limited in time by the terms of the contract. If the creditor in the prescribed period makes a claim to the debtor to fulfill the obligation, the term of performance of the obligation. If within one month (for the loan agreement there is a special rule on the duration of the regulatory obligation by the borrower - Part 1 of Article 1049 of the CCU) the loan is not repaid, the obligation is overdue, there is a corresponding security relationship between counterparties.

A slightly different situation arises when the creditor does not apply to the debtor within the period specified by the parties to the contract. From what moment then does the course of the regulatory relationship begin, and does it begin at all? When will it expire and is it possible to protect such a civil right? Frankly, it is doubtful to consider the right of a creditor who has not applied to the debtor to fulfill the obligation and lost the opportunity to do so violated. In our opinion, the debtor's obligation to perform certain actions in favor of the creditor will become overdue only after the expiration of the period given to him to perform after the latter's application. In other words, although the obligation arises at the time of the conclusion of the relevant contract, until a certain time associated with the claim of the creditor, it is unenforceable. It follows that the

\footnotetext{
${ }^{6}$ Крашенинников Е.А. Правовое положение сторон отлагательно обусловленной сделки во время состояния подвешенности. Очерки по торговому праву : сб. науч. тр. / под ред. Е.А. Крашенинникова. Вып. 12. Ярославль, 2005. С. 13.

Zimmermann R. The Law of Obligations. Roman Foundations of the Civilian Tradition. Oxford University Press, 1996. P. 717-719.
} 
creditor's right is not violated due to non-performance of the obligation, and therefore cannot be protected. However, in the literature and law enforcement practice (actually, without any legal justification) a different approach to this problem is used. Despite the fact that the creditor has not exercised his right within the period prescribed by contract or law and has not filed a claim for performance of the obligation, it is considered that his right is still violated. And the day of the offense is the last day when he could make a regulatory claim to the debtor. We have already made proposals to adjust the regulatory framework in this area ${ }^{8}$.

In the sense of the considered problems, the question is interesting, how widespread are the legal relations in civil circulation, in which the term of performance of the obligation by the debtor is not established or determined by the moment of filing the claim by the creditor? Obligations with an indefinite period of performance are quite common in such civil law agreements as storage, loan, lease, power of attorney, etc. These contracts may not contain conditions on the term (term) of performance, which does not make them defective. As well as in contracts in which the term (term) is stipulated by the moment of the requirement, performance of the obligation by the debtor should occur with occurrence of a certain event - presentation of the similar requirement. The condition of the contract, according to which the term of payment for the product must come some time after the creditor's invoice for the monetary obligation, looks a little different. This situation is typical for contracts for the supply of certain types of resources: oil, gas, electricity and heat, water and more. Contracts that mediate such relationships are long-term in nature, the value of the goods supplied for a certain billing period is often determined by the needs of the buyer and is set, as a rule, in the form of a threshold. The actual value of the goods is specified based on the results of the settlement period and the amount of funds payable is made out by the settlement document. That is, the contract specifies the contractual value of each periodic delivery (otherwise, in the absence of this essential condition, the contract cannot be considered concluded), but it can sometimes differ significantly from the actual received. At the same time, the parties to the agreement agreed that the payment of each period should take place after the creditor draws up and issues such a settlement document.

In this case, there is also a determination of the deadline at the request of the creditor. But this situation is fully consistent with the principles of good faith execution. The term of payment is usually not essential for most civil law contracts. Therefore, the certainty of the term of payment at the time of the creditor's claim (or even its uncertainty in general) does not bring the contract inconsistent with the law. If, according to the content of the contract, payment is to be made only after the invoice has been issued, the

${ }^{8}$ Гуйван П.Д. Теоретичні питання строків у приватному праві : монографія. Харків : Право, 2014. С. 299-303. 
debtor's obligation to pay begins after the creditor has taken the appropriate action. This rule should apply even in cases where the debtor can independently, without obtaining an invoice to establish the amount of its debt. Invoicing should be equated with a creditor's requirement to meet an obligation when determining the timing of such a claim.

\section{Fulfillment of contractual obligations in time}

In Article 509 of the Civil Code, the legislator provides only an approximate classification of mandatory interactions. The creditor may demand, and accordingly the debtor must take the following actions: transfer property, perform work, provide a service, pay money, and so on. Of course, this list does not exhaust all the options for the possible behavior of the parties to the obligation in terms of the content of the claim and the proper performance of the duty, but it is in view of this subject historically classified civil contracts in our legislation ${ }^{9}$. This is how the special part of the law of obligations in the Civil Code of Ukraine and other post-Soviet states is constructed ${ }^{10}$. We adhere to the same principle in the study of temporal mechanisms of regulation of specific contractual relations.

However, even in the given inexhaustible list of obligatory relations one of them which has universal character and is realized in practically each of blocks of contractual material relations is striking. This is a so-called monetary obligation. According to him, the debtor (regardless of what he has to transfer funds for: for the goods received, work performed in his favor or service received) must pay money, and the creditor has the right to demand such an obligation. Of course, the features of the subject of execution are determined by the specifics of a particular legal relationship, the grounds for the obligation and the degree of regulatory regulation. However, given the mostly equivalent nature of material interactions in modern property circulation, most of them include obligations under which the debtor must transfer (pay) money, and the creditor has the right to demand such action. Such obligations are called monetary, they are most common in civil and commercial relations. Moreover, the current Ukrainian legislation pays special attention to the regulation of monetary obligations, often specifying certain general rules concerning the subject of execution (Articles 524, 533-537 of the CCU, 198 of the ECU).

Special legal support (Article 625, Part 2 of Article 1214 of the CCU, Part 6 of Article 231 of the Economicall Code) is also devoted to liability for non-fulfillment of monetary obligations, which once again emphasizes the exceptional importance of this relationship. Therefore, the issues of determining the legal content of both the monetary obligation itself and the

9 Гордон М.В. Лекции по советскому гражданскому праву. Харьков : Изд-во Харьковского ун-та, 1960. Ч. 2. С. 5-6.

10 Луць В.В. Сучасна кодифікація договірного права в Україні: здобутки і проблеми. Вісник Академії правових наук України. 2003. № 2 (33). С. 435. 
responsibility for its violation, the establishment of the initial and final terms of both regulatory and protective legal relations, are quite relevant. It should be agreed with V.V. Luts that the issues concerning the application of sanctions, in particular civil liability, are closely related to the term of the regulatory obligation. Such consequences occur if the violation occurred during the existence of the latter. When committing an offense outside the scope of a regulatory relationship, a person may be held liable under rules established for non-contractual obligations, such as causing harm ${ }^{11}$. In this context, the analysis of the civil and economic legislation of Ukraine and the procedure for its application in the occurrence, implementation and breach of a monetary obligation deserves special attention. It should be noted that a single concept of the proper performance of duties, the subject of which is the payment of funds, has not yet been developed, especially in the analysis of modern literature and examples of law enforcement practice concerning the grounds, timing and application of legal consequences of improper performance of monetary obligations. The variety of current legislation and differences in judicial practice only underscore the problem.

In a binding legal relationship, the debtor must take certain actions in favor of the creditor, to perform a monetary obligation such an action is to pay. Failure to meet this obligation within the specified period (term) is a violation of the creditor's right. The latter, in turn, must monitor the progress of the duty, so it is considered that he should be aware of the violation of civil law from the moment of its delay. Therefore, the very definition of the moment of violation of a subjective right needs additional analysis. Much depends on a clear understanding of the question "when there was a violation of a right or interest": both the possibility of applying the sanctions provided by law or contract, and the beginning of the period for judicial protection. However, in order to define the concept of delay, it is first necessary to establish when and on what legal basis the obligation arose, which later turned out to be violated, and what was the term of its fulfilment. The start and end dates of the regulatory obligation to pay money are generally known to counterparties from the beginning of the legal relationship, as the term as a condition that characterizes the content of the obligation is mainly determined by the parties to the contract or regulations. As a variant of such regulation should be considered and provided in P. 2 of Art. 530 of the CCU, the case when the term is determined by the creditor's claim, which the latter has the right to present when he wishes. Then the period of proper execution will begin from the time of receipt of the request and expire in a week.

However, there are more sophisticated legal tools for determining the temporal factors of a monetary obligation. For example, a seller who has received a prepayment for the goods and has not delivered them on time

11 Луць В.В. Строки і терміни у цивільному праві : монографія. Київ : Юрінком Інтер, 2013. C. 127. 
must return the money at the seller's request, even though he has the opportunity to fulfill the goods obligation with delay (Part 2 of Article 693 of the CCU). In this case, failure to transfer the goods by the seller within the stipulated period leads to the same consequences in the case of the buyer's claim, regardless of whether the advance payment was made to fulfill the contractual obligation, or such action, not mandatory for the buyer, After all, in accordance with the rule of Art. 531 of the CCU, the debtor may, as a rule, fulfill the obligation ahead of schedule (in this case, make a prepayment). Such performance is proper, so the creditor must accept it. Therefore, it is quite logical that the current Ukrainian legislation does not correlate the emergence of new monetary obligations established by him to return the advance payment with the grounds for receiving an advance payment. In this situation, the occurrence of a regulatory obligation to return the funds requires a certain factual composition (a set of legal facts in a certain sequence) - receiving prepayment for the goods by the seller, overdue goods, the buyer's request for a refund. In this case, the monetary obligation, in which the debtor will be the seller, will also start from the receipt of the claim and will last for seven days ${ }^{12}$.

A monetary obligation to return funds also arises when the law classifies them as unreasonably retained or acquired. In this case, it is somewhat more difficult to establish a "normal" period for the fulfilment of a monetary obligation. Article 1212 of the CCU does not specify for how long it is necessary to fulfill the obligation to return such property, including when it was once legally acquired, but the proper grounds for such acquisition subsequently disappeared. I think that in such circumstances in practice should be guided by the concept of reasonableness of the term. So, as we can see, the legal basis for regulatory monetary obligations may be different: the contract, the creditor's claim, a complex set of legal facts, etc., but their content remains the same - the debtor must pay money on time, and the creditor has the right to demand such behavior. The term of the obligation is a condition ${ }^{13}$, it is an integral part of its content. Unlike other obligatory relations, in which, in fact, there can be many ways of breach, nonperformance of a monetary obligation is almost always manifested in the debtor's failure to comply with the temporal component of its content, ie overdue. In this case, there are unfavorable for the debtor legal consequences established by the contract or act of law.

In fact, non-payment of money on time entails the same general sanctions as breach of any other obligation. Such means of liability as a penalty, recovery of damages, termination of the contract, etc. may be applied to the

12 Гуйван П.Д. Строки (терміни) виникнення, здійснення та захисту прав у зобов'язаннях, пов'язаних із попередньою оплатою товару. Вісник господарського судочинства. 2013. № 4. С. 118.

13 Спасибо-Фатєєва I.В. Вплив строку на договірне зобов'язання. Мала енцииклопедія нотаріуса. 2006. № 1. С. 40. 
debtor. However, as already noted, Ukrainian legislation, given the special status of monetary obligations, provided for special liability in the form of inflation charges, interest per annum (Part 2 of Article 625 of the CCU), interest for the use of other people's (non-refundable) funds Art. $536 \mathrm{CCU}$ ), a special penalty (Part 6 of Article 231 ECU). All these negative consequences of non-performance of a monetary obligation are realized within the protection of the legal relationship, which arises from the time of the violation and has a claim, ie can be enforced with the help of jurisdictions.

At first glance, such a large number of general and special sanctions against the improper monetary debtor should indicate the increased concern of the legislator to stabilize the property turnover by legally ensuring the timeliness and proper settlement. But, in fact, everything is not quite so. However, by introducing special means of liability for breach of a monetary obligation, the law did not provide an essential interpretation of them. As a result, in law enforcement practice today there is no unity on the application of certain types of liability. Thus, we have examples when for the same delay of a monetary obligation two methods of one type of responsibility ${ }^{14}$ (penalty and fine) are applied at the same time, or, on the contrary, when satisfaction of a court claim on application of responsibility is refused due to the fact that a certain sanction "Does not fit" to this offense ${ }^{15}$.

Meanwhile, the correct interpretation of the content of a particular rule of conduct is crucial to establish the scope and duration of the material relationship. Let's examine in more detail the practical application of these rules on the legal consequences of breach of monetary obligation. One of the general legal principles of regulation of commodity relations is as follows: if the law defines an interaction as mandatory, its violation will inevitably lead to liability. However, this seemingly unshakable thesis, unfortunately, is not always reflected in law enforcement practice. In fact, we receive numerous court decisions, which, noting the non-fulfilment of a monetary obligation, do not consider it necessary or possible to apply remedies to the violator. The most common grounds for refusing to prosecute a monetary debtor are the following: a) the obligation to pay is specific, "unusual", non-monetary in the sense of Art. 625 of the CCU, so liability for breach of monetary obligation does not apply to this relationship; b) the obligation to pay funds, although it is monetary, but because it did not arise from the contract, in its violation cannot be applied liability under the law; c) penalty for the specified violation can be applied only when it is established in the contract.

Let's try to understand the validity of such approaches. Much has been said about the obligation that one person must pay and the other has the right

14 Постанова Верховного Суду України від 27.04.2012 p. URL: http://document.ua/pro-stjagnennja-infljaciinih-vtrat-3-25-richnih-peni-ta-shtrdoc 100851.html..

15 Постанова Вищого господарського суду України від 22.08.2013 р. по справі № 910/2589/13. URL: http://www.reyestr.court.gov.ua/Review/33101331. 
to demand. It cannot be any other. However, in court decisions we often come across a phrase like this: in essence, the obligation to return the money received, for example, as a prepayment, cannot be regarded as a monetary obligation within the meaning of Article 625 of the Civil Code of Ukraine. Unfortunately, this approach is quite widespread in judicial practice today. But it is not based on legal acts. First, the norm of Art. 625 of the CCU does not define the concept of monetary obligation, but only establishes the consequences of its violation. This rule shows that it is imperative and applies to any breach of monetary obligation, regardless of its nature and grounds. Second, civil and commercial law, which defines a monetary obligation, also does not distribute it artificially according to certain circumstances, as the law enforcement agency suggests. An obligation is monetary if its content includes the debtor's obligation to transfer funds and the creditor's right to demand performance of this action (Part 1 of Article 173 of the Economical Code, Part 1 of Article 509 of the Civil Code).

It should be borne in mind that monetary obligations are not divided on the basis of origin ${ }^{16}$. As D.I. Meyer rightly pointed out, money is the subject of obligations, and this is natural, because obligations are adjacent to the sphere of property rights, and all property is valued in money ${ }^{17}$. Therefore, all monetary regulatory obligations have the same meaning: to pay for goods, work or service (including in the form of prepayment or in installments), for the use of someone else's property (including money), return of prepayment, as well as other people's funds received in urgent use or unreasonably, etc. All of these obligations have the same obligation to transfer the money to the lender. If the grounds for the monetary obligation do not affect its content (ie, regardless of the content of the counterobligation: to transfer the goods, perform work or otherwise), the nature of the relationship may determine the specifics of the relevant right of the person. We are currently talking about a certain difference in the content of regulatory and security monetary obligations. Opinions about their slightly different essence have already been expressed in the literature. In particular, the latter arises as a result of the offense and is that the violator in addition to the requirement to fulfill obligations in kind are subject to additional monetary obligations: to pay penalties and interest for misuse of other people's funds, damages and non-contractual damages acquisition or preservation of property without a sufficient legal basis, etc ${ }^{18}$.

${ }^{16}$ Методологічні засади охорони та захисту майнових прав осіб в Україні та СС. Монографія. / За заг. ред.. О.Д. Крупчана. Тернопіль : Підручники і посібники, 2008. C. $120-121$.

17 Мейер Д.И. Русское гражданское право / Ред. Е.А. Суханов и др. Ч. 2. Москва : Статут, 1997. С. 129.

18 Лавров Д.Г. Денежные обязательства в российском гражданском праве : автореф. дис. ... канд. юрид. наук. Санкт-Петербург, 2000. С. 12-14. 
However, the chapters of the Civil and Commercial Codes, which regulate liability, also do not make exceptions to the application of legal consequences in the event of a breach of certain obligations, distinguishing them on the merits. In particular, the provisions of Chapters 51 of the CCU and 26 of the ECU apply to all (including all monetary) obligations. If the law deems it necessary to somehow separate the responsibility for the offense in a particular legal relationship, it directly indicates this (for example, Part 2 of Article 231 of the Commercial Code formulates a different than general, way to prosecute participants in economic relations, where the party is project belonging to the public sector of the economy). Thus, the position that the violation of certain, essentially monetary obligations does not give rise to liability, has no legal basis.

The thesis of inapplicability of liability in case of non-contractual occurrence of a monetary obligation is also subject to critical evaluation. In any case, such a conclusion does not follow from the current legislation. And the case law, despite its heterogeneity, also mostly adheres to the view that the violation of the obligation, which arose, say, from the unjustified acquisition of money, entails liability under Part 2 of Art. 625 CCU. Therefore, liability for non-performance of a pecuniary obligation does not depend on whether such an obligation was agreed by the parties or arose, for example, from an act of law. Yes, the obligation to return the prepayment referred to in Part 2 of Art. 693 of the CCU, is contractual, although the parties did not agree. Indeed, modern legal science on the basis of analysis of existing acts distinguishes between the legal concepts of "condition of the contract" and "condition established by the parties". The first of them is more capacious. Terms of the property contract can be established not only by its participants. They are sometimes imperative (for example, when the transaction price is regulated). There is also a third way to form the content of the contract. The legislator gives one of the parties the right in certain circumstances to establish the terms of the agreement by committing a specific unilateral act.

For example, Article 309 of the Commercial Code gives the shipper the right to change the conditions of carriage by receiving back the goods handed over for carriage, replacing the consignee specified in the transport document, disposing of the goods in case of non-acceptance by the consignee. Therefore, the obligation of the carrier to take a certain action will arise only after the claim is made by the shipper. The consent of the carrier is not required for such an obligation to arise. Nevertheless, the rights and obligations that will constitute the content of such a new obligation will constitute the essential terms of the contract. The same applies to the monetary obligation to return the prepayment by the seller who did not deliver the goods on time. It arises from the unilateral action of the buyer, but is part of the contract. The same monetary obligation as others that have as their object the transfer of money. 
Finally, the thesis of non-application of penalties if they are not stipulated in the contract does not stand up to criticism. If this were the case, then non-contractual obligations would have no protective effect at all. Ukrainian legislation has repeatedly stated that penalties (penalties) can be established both by contract and by law. Moreover, the Commercial Code generally sets the priority of the normative definition of the penalty: if the amount of penalties is not defined by law, the sanctions are applied in the amount provided by the contract (Part 4 of Article 231 of the Commercial Code). Thus, the refusal to impose penalties in court can be only when they are not established by law or contract ${ }^{19}$.

\section{Liability for overdue monetary obligation}

It is easy to notice that with the legal uncertainty of the legal nature of certain consequences of non-performance of a monetary obligation ${ }^{20}$, we get a situation in which there are rules in Ukrainian law that either have no practical application or are applied by jurisdictions contrary to their legal nature. For example, it is difficult to understand why the direct rule of law Part 6 of Art. 231 of the Economical Code, is practically not used as a means of liability. What was not called the consequence provided for in it: and the payment of interest for the use of other people's money, and the kind of consequence provided for in Art. 625 of the CCU, but not the penalty established by law for non-performance of a monetary obligation. Meanwhile, only the situation commented in this article corresponds to the rule when the breach of a monetary obligation consists in non-refund. There is no need to look for another obligation of such content. Thus, if we accept the position according to which the non-fulfillment of the obligation to return someone else's money and the penalty calculated during the duration of their use are not correlated, we must conclude that the rule of Part 6 of Art. 231 of the Commercial Code is "dead". Because then in the nature of trade there will be practically no relations, the violation of which would entail similar consequences. We are far from believing that the dear developers of the Commercial Code of Ukraine aimed at just such a thing the symbolic state of this regulation. On the contrary, it is quite obvious that they, introducing a special rule for a certain circle of relations, hoped for its proper effectiveness. Moreover, the law does not provide for the possibility of reducing the effect of its application to zero.

In view of the above, it should be noted that in the legal literature and case law there is often a confusion or even identification of two essentially different security obligations arising from the payment of interest for the use of other

${ }^{19}$ Хозяйственное право: учебник / под. ред. В.К. Мамутова. Киев : Юринком Интер, 2002. С. 874.

20 Сальникова Г.І. Деякі проблеми застосування господарських санкцій за порушення договірних грошових зобов'язань. Вісник Національного університету «Юридична академія України імені Ярослава Мудрого». 2012. № 2(9). С. 259-260. 
people's money and a special penalty for breach of monetary obligation. In fact, the liability for non-performance of a monetary obligation (non-payment of funds) and for their subsequent misuse are different in terms of origin and time coordinates. Thus, according to the legislator, the penalty under Part 6 of Art. 231 of the ECU is a consequence of non-fulfilment of a monetary obligation - to pay money, the statute of limitations on this requirement is one year. Instead, liability in the form of interest (Article 536 of the CCU) arises for the further use of other people's funds and the claim lasts for three years. Therefore, we must conclude that the sanction provided for in Part 6 of Art. 231 of the Economical Code is a type of penalty imposed for nonperformance of a monetary obligation: it is applied if the parties have not set another amount within the limits set by the Law of Ukraine "On Liability for Non-performance of a monetary obligation". The duration of the period of accrual of penalties in the form of interest here by virtue of the prescription of a special rule of Part 4 of Art. 232 of the Economical Code differs from the general for the penalty - six months and is the entire period of the offense (in our opinion, this approach is unjustified). At the same time, liability under Article 536 of the CCU is not a penalty.

We believe that the problem of unjustified identification of these sanctions is largely caused by a uniform regulatory approach to determining the amount of various monetary obligations: in both cases, the amount of the sanction is calculated as a percentage (percentage) of monetary debt, and its base is associated with the duration of use. This is a disadvantage, but unfortunately it can hardly be eliminated. Of course, it would be possible to abolish some types of liability as ones that to some extent duplicate the existing ones. However, in the absence of market discipline, legal doctrine and legislation are now moving towards increasing liability for noncompliance, especially monetary ones, by introducing new independent types of sanctions. At the same time, there are not many ways to calculate their size: a fixed amount, a one-time percentage of the default, the same percentage for each day of delay. For monetary obligations, the latter option is the most effective. Therefore, in such circumstances, the law enforcement authority must carefully clarify the nature, grounds, and duration of the sanction when considering disputes.

The dynamics of property relations in society requires adequate and unambiguous regulatory support. The content of the obligation must be clearly understood by both the parties and the body resolving the dispute. In particular, the scope of the relevant rights and obligations, the moment of their beginning and end, the consequences of the violation, etc. must be determined. Unfortunately, such an approach does not always exist, confusion and ambiguity of current legislation results in unjustified expansion of judicial interpretation of the content of ambiguous rules, which leads to polar conclusions when considering the same type of relationship or the existence of so-called "dead" rules that do not apply. The most significant in this sense is 
the practical application of the law governing the procedure and duration of the obligation to pay for the use of other people's money.

The very concept of use has an integral characteristic of time - duration. In accordance with Part 1 of Art. 536 of the CCU for the use of other people's money should pay interest. In order to identify certain patterns of legal regulation in this matter, it is first necessary to understand what legal meaning the legislator puts in the definition of "foreign funds". There are not many cases when the civil legislation of Ukraine speaks about the need to pay for the use of other people's funds. Such an obligation arises, for example, in situations where, at the request of the buyer, the seller who has delayed the transfer of the goods must return the advance payment (Part 3 of Article 693 of the CCU). A similar obligation arises for a person who has acquired or retains unreasonably alien funds (Article 1212 of the CCU). In this case, the concept of "foreign money", according to the idea of the law, should not be narrowly understood only as money received in due time from another person. Thus, the law in Part 3 of Art. 692. Part 5 of Art. 694 of the CCU gives it a broader meaning, which also covers funds that did not arrive on time for the delivered goods. A broad understanding of the acquisition of someone else's property (funds) is manifested, for example, in the case when the buyer under the contract of sale has not fulfilled the obligation to pay for the goods in a timely manner ${ }^{21}$. Therefore, in addition to this obligation, he must pay interest for the use of other people's money. In other words, the property owned by the buyer, which he had to pay for the goods, from the moment of delay become "foreign" to him, and it is in the return of other people's money lies the content of such a monetary obligation, which lasts from the beginning of the delay to the actual transfer of money. Of course, this approach can hardly be considered perfect in terms of the principles of property law, but it certainly clearly characterizes the symptoms of modern binding presumptions.

At the same time, the legislator for some reason limited the scope of repayment of the use of other people's money only by the contract of sale. After all, the relationship regarding the use of money, which should have been paid (returned) to the creditor, may arise in the implementation of other relationships in the field of property circulation (commission, contract, deposit agreement and others). Therefore, these rules must be applied to them. Currently, the law uses the term "foreign money" only in relation to the money that was not paid in time by the buyer (Part 3 of Article 692, Part 5 of Article 694 of the CCU), used by the seller who received prepayment and did not properly transfer the goods (h 3 of Article 693 of the CCU) and those received or withheld without a proper legal basis (Part 2 of Article 1214 of the CCU). Instead, funds that are not paid on time by, say, a tenant (Article 762 of the CCU) or a bailor (Article 946 of the CCU), or received as prepayment by a contractor who fails to perform work on time, the Civil

${ }^{21}$ Науково-практичний коментар Цивільного кодексу України: У 2-х т. / За ред.. О.В. Дзери, Н.С .Кузнєцової, В.В. Луця. Київ : Юрінком Інтер, 2006. Т. 2. С. 952. 
Code does not provide such status. It is all the more surprising that the law does not consider "foreign" even the funds that the borrower continues to use after the expiration of the loan agreement. We believe this is a shortcoming of the current legislation. The literature has long argued that all paid property relations are, in fact, elements of the sale of goods. In this case, the goods should be understood as property, work, service, property rights, and so on ${ }^{22}$. This approach can be assessed in different ways, but the general features of monetary obligations in all these respects are striking.

For example, under a loan agreement, the lender transfers certain funds to the borrower for a certain period, and the latter must return the same amount of money after the expiration of this period. During this regulatory relationship, the borrower has the right to use the money, and the duty of his counterparty is passive behavior: he must refrain from obstructing the exercise of his powers by the creditor. At the same time, the content of the contract includes a counter-obligation to pay for the use of the funds provided. Usually, the usage fee is calculated as a percentage of the amount used by the borrower. Periods, amount and terms of payment are set by contract, and in the absence of agreement - by law (Part 1 of Article 1048 of the CCU). During the term of the agreement, if the borrower's actions comply with the terms of the agreement, we cannot qualify them as the use of someone else's money. This would contradict both the content of the agreement and the very principle of dispositiveness.

There is also another obligation in the loan agreement to return the same amount of money to the borrower. In it, the borrower is the debtor. When should such a duty be fulfilled? Strictly speaking, this should be done before the expiration of the contract, unless the contractors have provided for a grace period for the return of funds. If the period of use of the loan has not been agreed, the borrower must repay the money before the end of the one-month period, which is calculated from the day following the claim filed by the lender.

All the above relations are regulatory in nature and occur within the lawful conduct of the parties to the agreement. If after the expiration of the terms set for use the money will not be transferred to the lender, there is another legal relationship - security. The borrower's actions regarding the use of funds will be considered illegal, and the content of the claim, which can be implemented within the limits of this protective authority, will first be expanded (it will include not only the right to demand repayment). to apply the consequences of violation of its regulatory right provided by law or contract), secondly, will have the ability to enforce. Therefore, it is from the moment of such violation (overdue monetary obligation to return the funds) that the funds, which are now illegally withheld by the subject, become "foreign" to him. Therefore, from now on the rule of Part 1 of Art. 536 of the CCU on the need to pay interest for the use of other's money.

${ }^{22}$ Брагинский М.И. Общее учение о хозяйственных договорах. Минск : Наука и техника, 1967. С. 30-39. 
These things are actually quite obvious, but for some reason they are not reflected in our legislation. So far, it has a special and rather narrow nature in the application of the definition of "foreign funds", which is incorrect. Therefore, if we want uniformity in ensuring the circulation of property, it is necessary to make a general rule governing the use of other people's funds. In this regard, it is sometimes useful to adopt the positive experience of the legislation of other countries. Thus, our neighbours in the near abroad seem to have more settled issues: the use of other people's money arises as a result of their illegal withholding, evasion of return, other delay in payment, or unreasonable acquisition or retention at the expense of another person (Part 1 of Article 366 of the Belarus Civil Code, Part 1 of Article 395 of the Russian Civil Code). The introduction of such a rule in Ukrainian law is relevant, it will extend the mechanism of repayment of the use of other people's funds to all relations, not just purchase and sale, while additional regulation of this issue by separate rules (eg Part 3 of Article $692 \mathrm{CCU}$ ) will not be required.

Thus, Ukrainian law states that under certain circumstances, the money held by a person in the right of ownership begins to qualify as someone else's. At what point does this happen? The analysis suggests that in all cases, without exception, this status is acquired from the period of noncompliance with the regulatory obligation, so it deserves a critical assessment of the position that the accrual of interest for the use of other people's funds is within the regulatory relationship ${ }^{23}$. In this case, the unfulfilled obligation as a legal basis for a refund can be both material and monetary, for example, non-payment for the goods received, non-delivery of products by the seller who received prepayment, and so on. In any case, a new obligation arises, the subject of which is a refund.

As a general rule, the regulatory obligation to return funds as a result of their unjustified receipt arises from the moment the purchaser becomes aware of this fact and will last for a reasonable period of time to fulfill this obligation. With the omission of this period, during which the performance of the non-contractual obligation was due, security interactions arise. Therefore, it is from this moment that the use of other people's money should be qualified as illegal, so it is the beginning of the existence of a protective requirement to pay interest. In view of the above, we must recognize the wrong approach used by researchers and law enforcement practice, when the accrual of interest begins from the moment of unjustified receipt of someone else's money. In fact, the protective content of such a relationship is more fully matched by the rule that the debtor (a person who uses someone else's money after the end of the regulatory relationship regarding their return) must pay the creditor for such use. This obligation from the time of its inception becomes part of the

${ }^{23}$ Цивільне право України: Підручник: У 2-х т. / Борисова В.І., Баранова Л.М., Жилінкова І.В. та ін. За заг. ред. В.І. Борисової, І.В. Спасибо-Фатєєвої, В.Л. Яроцького. Київ : Юрінком Інтер, 2004. Т. 2. С. 27. 
protective relationship for breach of contract of sale, but it arises not by agreement of the parties, but by law.

It is well known that the fee for the use of other people's money is a certain percentage (percentage) of the amount of money used. What is the amount of payment for the use of other people's money? In Part 2 of Art. 536 of the CCU states that it is determined by contract, law or other act of civil law. It is good when the parties to, say, a contract of sale at its conclusion stipulated the level of interest for the use of funds when they become alien to the debtor. Then the above question has a simple answer. However, practice shows that such a condition is not always agreed by the parties. This is especially true in cases where the monetary obligation, in case of nonfulfilment of which interest must be paid, arises not from the contract, but from the law (for example, parts 2, 3 of Article 693 of the CCU). And provided that someone else's money is acquired or saved without a proper legal basis (Article 1212 of the CCU), there can be no question of a contractual settlement of the level of such payment. Despite the existing proposals in the literature on a radical narrowing of the grounds for charging interest on the use of other people's funds in the event of their unjustified acquisition or retention ${ }^{24}$, this rule is still general in nature. In such circumstances, how to determine whether it is necessary to make a payment for the use of other people's money, and, if so, what is the amount of this payment?

It should be noted that modern case law also does not provide an unambiguous answer to this question. We have numerous examples of different approaches in the jurisdictional resolution of such disputes. In fact, we can distinguish three completely different approaches that occur in law enforcement practice: the first - the courts generally refuse to collect fees for the use of other people's money, the second - argues for the certainty of payments for the use of other people's money in Part 2 of Art. $625 \mathrm{CCU}$ at the level of three percent per annum. Finally, as a third option, by analogy with the law, Article 1048 of the CCU is used, and this amount is calculated according to the rule governing the payment of interest on the position. In our opinion, all these options have certain shortcomings, some major, others minor, they do not always comply with the principles of adequate substantive regulation of these property relations.

Let's analyze in detail the current legislation in this area. To establish whether such a situation is possible, when interest for the use of other people's money does not need to be paid at all, we will more meticulously assess the content of the norm of Part 1 of Art. 536 CCU. To do this, we first clarify the legal component of the differences between the legal definitions "if it is provided in the contract" and "if otherwise not provided in the contract". It is obvious that they have a completely different meaning, and they should not be identified in any case. The first of these phrases means that certain legal

${ }^{24}$ Хохлов В.А. Ответственность за пользование чужими денежными средствами. Хозяйство и право. 1996. № 8. С. 40-41. 
consequences will arise only when the parties have agreed. No legal requirements may give rise to any rights or obligations. The second normative statement has the interpretation that the order of conduct of the parties is established by a legal act, but may be changed by agreement of the counterparties. Now in the context of this analysis, let's look at the content of the rule that regulates the issue of payment for the use of other people's money. Part 1 of Article 536 of the CCU states literally the following: the debtor is obliged to pay interest for the use of other people's money, unless otherwise provided by contract between individuals. Therefore, for the use of someone else's funds in cases where such use is established in accordance with the contract or the law, the funds should always be paid, even if the parties have not agreed. Exceptions to the general rule are cases where all parties to the relationship are natural persons and have expressly agreed to waive the monetary obligation. It is the substitution of the above presumptions that can explain the emergence of the recently widespread position of Ukrainian law enforcement agencies in resolving disputes, according to which in the absence of a contractual settlement by the parties the interest on the use of foreign funds is not charged at all. Obviously, this approach is not in line with the Civil Code rule on the obligation of these payments.

But then what should be the amount of interest for the use of other people's money? It is believed that the law still determines the level of such payments, and it is specified in Part 2 of Article 635 of the CCU in the form of three percent per annum. This conclusion is certainly obvious if we look at the numerous casual decisions of the Supreme Court of Ukraine that have been made recently. In assessing the grounds or terms of recovery of 3\% per annum, the court usually determines the legal nature of this claim, stating that the interest is "compensation (payment) from the debtor for the use of the money withheld by him to pay the creditor". So, it would seem that everything is simple: the obligation to pay money for the use of other people's money is monetary, and 3\% per annum is the result of its violation. Therefore, since the annual fees are for the use of the creditor's money withheld, they are the interest that must be paid in accordance with the provisions of Articles 536, 1214 and others. If the amount of interest is stipulated in the contract, it should be applied directly under the prescription of Art. 536 of the CCU, while Part 2 of Art. 625 does not apply in such circumstances.

However, in fact, it turns out not so clear. Let's start with the fact that the Ukrainian courts, including the Supreme Court, arguing that 3\% per annum is a fee for the use of other people's money, still do not apply the norm of Part 2 of Art. $625 \mathrm{CCU}$ in the recovery provided for in Art. $536 \mathrm{CCU}$ interest. On the contrary, the case law has numerous examples when the debtor is charged three percent at the same time, provided for in Part 2 of Art. $625 \mathrm{CCU}$, and the interest specified in the contract for the use of other people's money. And if in satisfaction of requirements on collecting of percent for use of another's means according to Art. 536 of the CCU refuses, not because it is, in fact, already collected on this claim 3\% per annum, but for another reason (for example, 
due to disagreement on their size in the contract) ${ }^{25}$. This approach, at least, calls into question the above thesis about the equivalent-compensatory nature of three percent per annum.

Moreover, the position according to which are provided in part 2 of Art. $625 \mathrm{CCU}$ per annum is a fee for the use of other people's money, is not established in doctrine and law enforcement practice. Thus, the position of the Supreme Economic Court is known, according to which "the interest provided for in Art. 536 and Part 3 of Art. 693 of the Civil Code of Ukraine - on the one hand, and the interest provided for in Art. 625 of the Civil Code of Ukraine on the other hand, these are different legal phenomena, in connection with which each of these types of interest is applied in the presence of appropriate grounds, which are different. With this in mind, if there are legal grounds, it is possible to simultaneously apply interest on the basis of Art. Art. 536, 693 of the Central Committee of Ukraine, - on the one hand, and the percent provided by Art. 625 of the Civil Code of Ukraine - on the other. Some documents of the Supreme Court also indicate the compensatory nature of 3\% per annum, similar to the penalty, so it is proposed to apply to them the provisions of Part 3 of Art. 551 to reduce their size in certain circumstances. Opinions of scientists on this subject also differ considerably.

At the same time, doctrinal approaches to assessing the legal nature of interest under Part 2 of Art. $625 \mathrm{CCU}$ need more meticulous analysis. Unfortunately, many researchers, in determining the legal nature of interest, do not see a fundamental difference between interest for the lawful use of funds provided, on the one hand (for example, in a position), and interest paid in breach of a monetary obligation, on the other. Meanwhile, the essence and temporal characteristics of such relations are completely different. The first has a regulatory nature, arises with the entry into force of the contract. Such a monetary obligation to pay for the use of the funds provided is assessed by all scholars in the same way: it is of a compensatory nature and expresses the value of the property (funds) that is transferred to another person for a certain period of time. Instead, the obligation to pay interest per annum, provided for in Part 2 of Art. $625 \mathrm{CCU}$ does not arise from the contract, but from the law (the parties can only change the amount of interest, but not the grounds for their occurrence). Such an obligation arises as a result of a breach, so it is protected by law and from the moment of breach, ie from the very beginning of its existence, endowed with the ability to enforce. In other words, the statute of limitations expires from the time the obligation arises from this obligation. The legal assessment of the essence of this relationship in the literature and law enforcement is different. Thus, there is a thesis that boils down to the identification of those specified in Art. 625 of the CCU per annum, in essence, with the obligation to pay for the use of the funds provided by the parties in the loan agreement. In other words, this obligation is of a regulatory nature. It is impossible to agree with such

${ }^{25}$ Постанова Верховного Суду України від 20 серпня 2013 р. у справі 3-22гс/13. URL: http://www.scourt.gov.ua/clients/vsu/../3-22гс13.doc 
conclusion as the specified legal relationship is not endowed with signs of regulatory, and, on the contrary, has all displays of protection. As a result, most scholars are inclined to give annual interest the status of liability. The controversy continues only over whether to consider annual penalties, an independent form of liability, or a special kind of damage ${ }^{26,27}$.

Against this doctrinal background, the existing in judicial practice assessment of the legal content provided for in Art. $625 \mathrm{CCU}$ interest per annum. The legal position is that these consequences of overdue monetary obligation are not sanctions, but a way to protect property rights and interests. This approach only confuses the already ambiguous situation. After all, as you know, the sanction is part of the logical structure of any regulatory rule of law, it establishes the legal consequences that occur in case of non-compliance with the terms of the disposition. Thus the sanction can be specified both in the article regulating relations (for example, h. 6 Art. 231 EKU, h. 1 Art. 725 $\mathrm{CCU}$ ), and in special chapters (ch. 3, $82 \mathrm{CCU}$, section V ECU). The sanction of any legal norm is the normative definition of the limits of state coercion, which is applied in case of an offense. The protection of the violated subjective right of a person can be carried out only in a manner authorized by law. Therefore, the application of sanctions to the violator established by law is the implementation of certain ways to protect their rights. In any case, this is how the mechanism of application of economic sanctions, provided, for example, in Art. 216, 217 ECU. Therefore, the payment established in Art. 625 of the CCU interest is clearly a sanction for non-performance of a monetary obligation.

But is this sanction a way of responsibility? The fact is that in the doctrine not every sanction defined by law in case of violation of rights qualifies as civil liability. The latter includes only those sanctions that impose additional burdens on the offender, which he did not exist at the time of the violation. Such burdens may consist in imposing additional civil law obligations on him or depriving him of his subjective right. In other words, liability as a kind of sanction is the imposition on the offender of unfavorable for him legal consequences, which are based on the law and are manifested in the deprivation of certain rights, replacement of the unfulfilled obligation with a new one or the emergence of additional. From this point of view, invalidation of a transaction, vindication, application of restitution, enforcement of a duty in kind are not liability, because a person as a result of judicial enforcement does not receive new responsibilities or loses rights (because he did not have it). Instead, the termination of the contract or the collection of a penalty is a liability, as the negative consequences for the violator are of a new nature. In view of this, $3 \%$ per annum have the nature of such a sanction as property

${ }^{26}$ Печений О.П. Прострочення виконання договірного зобов'язання : автореф. дис. ... канд.. юрид. наук. Харків : Національна юридична академія ім. Ярослава Мудрого, 2002. С. 9.

Попов Ю. Правовая природа так называемых «процентов годовых». Юридичний журнал. 2002. № 3. С. 55-57. 
liability, as the obligation to pay interest was absent before the violation and arose only after it ${ }^{28,29}$. This view is shared by most scientists. Finally, despite numerous claims against Ukrainian legislators, it is difficult to argue in this case that they were unaware of the legal nature of the rule they included in the article entitled "Liability for breach of a monetary obligation" in the chapter "Legal consequences of breach of obligation". Liability for breach of obligation". As for the specific type of such liability, the points of view of O.P. Podtserkovny, who considers interest under Art. $625 \mathrm{CCU}$ one of the forms of damages (similar to lost profits), the amount of which is determined in advance by law in connection with the universality and economic usefulness of money as their original legal properties, and V.V. Vitryansky, who gives them an independent civil liability along with penalties and damages. Both of these approaches have their advantages and disadvantages (this is not the subject of this study), but the main thing is that they clearly delineate the debtor's liability in the form of annual interest on penalties.

\section{CONCLUSIONS}

As a result of the study of the temporal and essential factors inherent in the binding relationship, and ways to exercise the protective powers of the bearer, aimed at protecting their rights, we obtain the following conclusions. Regulatory monetary obligations have the same legal essence and meaning: the creditor's right to demand money and the debtor's obligation to pay it, regardless of the grounds and content of the counter-obligation. From the moment the monetary obligation is violated, a protective relationship arises, which includes claims for the use of means of liability. As the law does not differentiate monetary obligations on any grounds, the procedure for applying the liability provided for in the contract or the law is the same for any violation. In case of overdue obligation (including monetary), various types of liability (of a legal nature) may be applied to the debtor. The application of different sanctions of the same type for the same violation (delay) is not allowed.

Given the analysis of the essence of the temporal factors of monetary obligations and in order to eliminate these shortcomings in the current legislation and to achieve uniformity of law enforcement, it is proposed to make the following changes to the current Ukrainian legislation.

1. The content of Part 4 of Art. 232 of the Commercial Code unjustifiably mixes the penalty for breach of monetary obligation with liability for the use of other people's money. In addition, the establishment

28 Гуйван П.Д. Строки (терміни) виникнення, здійснення та захисту прав у зобов'язаннях, пов'язаних із попередньою оплатою товару. Вісник господарського судочинства. 2013. № 4. С. 120-121.

29 Гуйван П.Д. Темпоральні аспекти виконання грошового зобов'язання та застосування відповідальності за його порушення. Підприємництво, господарство і право. 2014. № 1. С. 5-6. 
of a period of accrual of penalties other than that provided for in part 6 of this article, six months, reduces the rule of part 6 almost only to the regulation of sanctions for non-performance of non-monetary obligations, which is impractical. Given the above, this rule is proposed in Part 4 of Art. 232 ECU to delete. At the same time, its text can be inserted almost verbatim as part 3 of Art. $536 \mathrm{CCU}$.

2. The third paragraph of Part 2 of Art. 231 of the Commercial Code actually introduces double liability of the same type - economic penalties for the same violation. After all, starting from the 31st day of delay for this violation, both a fine and a fine are charged at the same time. This approach is hardly consistent with the general principle of non-liability for the same tort. It is proposed to state this norm in the following wording: "for violation of the terms of fulfilment of the obligation a penalty in the amount of 0.1 percent of the value of goods (works, services) from which delay is allowed by choosing a creditor instead of a penalty, a fine of seven percent of the specified value may be levied". This approach will certainly help to develop good contractual and judicial practice in the application of sanctions for non-performance of monetary obligations.

3. Part 1 of Article 536 of the CCU should be worded as follows: unless otherwise provided by agreement between individuals. The accrual of interest for the use of other people's funds begins after the expiration of a reasonable period for their return.

4. Introduce legislative certainty in Part 2 of Art. 625 of the CCU in terms of payment of interest per annum in case of overdue performance of a monetary obligation, regardless of the grounds for the latter. For example, it may be stated that in case of overdue performance of a monetary obligation, the debtor pays interest for the use of other people's money in the amount of the discount rate of the National Bank, unless otherwise provided by contract or law. This will ultimately eliminate the need for an analogy in the regulation of these obligations, which today seems entirely justified.

\section{SUMMARY}

The work is devoted to the study of the topical issue of the temporal characteristics of the contractual relationship. It is emphasized that the main principle of modern property turnover is the principle of proper performance of obligations, the essence of which, in particular, is that performance must be carried out by the parties in a timely manner. That is, in accordance with the terms of the contract and the requirements of the law, and in the absence of such conditions and requirements - in accordance with the customs of business or other requirements that are usually imposed - within a reasonable time. Describes the procedure for interaction of counterparties regarding the temporal certainty of the relationship, especially in the case when the term is not specified in the obligation. The order of presentation by the creditor of the corresponding requirement and ways of reaction to it by the debtor are regulated. Detailed attention is paid to the study of the legal 
mechanism that regulates the time parameters of the protective authority of a person in case of violation of his subjective right. The analysis of the civil and economic legislation of Ukraine and the order of its application at occurrence, realization and infringement of the monetary obligation is carried out separately. Specific proposals are provided to amend the current legislation in this area.

\section{REFERENCES}

1. Кузнєцова Н.С. Подрядные договоры в инвестиционной деятельности в строительстве. Киев : Наукова думка, 1993. 135 с.

2. Ромовська 3.В. Проблема загальної теорії права у проекті ЦК України. Кодифікація приватного (цивільного) права України. Київ, 2000. 292 c.

3. Beatson J., Burrows A., Cartwright J. Anson's Law of Contract. $27^{\text {th }}$ ed. Oxford. New York, 1998. 682 P.

4. Иоффе О.С. Избранные труды по гражданскому праву. Москва : Статут, 2000. $781 \mathrm{c}$.

5. Raiser L. Dinglishe Anwartschaften. Tubingen, 1961. $896 \mathrm{~s}$.

6. Крашенинников Е.А. Правовое положение сторон отлагательно обусловленной сделки во время состояния подвешенности. Очерки по торговому праву : сб. науч. тр. / под ред. Е.А. Крашенинникова. 2005. Вып. 12. С. 5-18.

7. Zimmermann R. The Law of Obligations. Roman Foundations of the Civilian Tradition. Oxford University Press, 1996. 1241 p.

8. Гуйван П.Д. Теоретичні питання строків у приватному праві : монографія. Харків: Право, 2014. 632 с.

9. Гордон М.В. Лекции по советскому гражданскому праву. Харьков : Изд-во Харьковского ун-та, 1960. Ч. 2. 288 с.

10. Луць В.В. Сучасна кодифікація договірного права в Україні: здобутки і проблеми. Вісник Академії правових наук України. 2003. № 2 (33). С. 424-437.

11. Луць В.В. Строки і терміни у цивільному праві : монографія. Київ : Юрінком Інтер, 2013. 320 с.

12. Гуйван П.Д. Строки (терміни) виникнення, здійснення та захисту прав у зобов'язаннях, пов'язаних із попередньою оплатою товару. Вісник господарського судочинства. 2013. № 4. С. 115-124.

13. Спасибо-Фатєєва I.В. Вплив строку на договірне зобов'язання. Мала енциклопедія нотаріуса. 2006. № 1. С. 35-41.

14. Постанова Верховного Суду України від 27.04 .2012 p. URL: http://document.ua/pro-stjagnennja-infljaciinih-vtrat-3-25-richnihpeni-ta-shtr-doc100851.html..

$\begin{array}{rlllr}\text { 15. Постанова } & \text { Вищого } & \text { господарського } & \text { суду } & \text { України } \\ \text { від 22.08.2013 p. по пе справі № } & 910 / 2589 / 13 . & \text { URL: } \\ \text { http://www.reyestr.court.gov.ua/Review/33101331. } & & \end{array}$


16. Методологічні засади охорони та захисту майнових прав осіб в Україні та СС. Монографія / За заг. ред. О.Д. Крупчана. Тернопіль : Підручники і посібники, 2008. 160 с.

17. Мейер Д.И. Русское гражданское право / Ред. Е.А. Суханов и др. Ч. 2. Москва : Статут, 1997. 455 с.

18. Лавров Д.Г. Денежные обязательства в российском гражданском праве : автореф. дис. ... канд. юрид. наук. Санкт-Петербург, 2000. 22 с.

19. Хозяйственное право : учебник / Ред. В.К. Мамутов. Київ : Юринком Интер, 2002. 910 с.

20. Сальникова Г.І. Деякі проблеми застосування господарських санкцій за порушення договірних грошових зобов'язань. Вісник національного університету «Юридична академія України імені Ярослава Мудрого». 2012. № 2(9). С. 257-264.

21. Науково-практичний коментар Цивільного кодексу України : У 2-х т. / За ред. О.В. Дзери, Н.С. Кузнєцової, В.В. Луця. Київ : Юрінком Інтер, 2006. Т. 2. С. 1088 с.

22.Брагинский М.И. Общее учение о хозяйственных договорах. Минск : Наука и техника, 1967. 259 с.

23. Цивільне право України : підручник У 2-х т. / Борисова B.I., Баранова Л.М., Жилінкова І.В. та ін. За заг. ред. В.І. Борисової, I.В. Спасибо-Фатєєвої, В.Л. Яроцького. Київ : Юрінком Інтер, 2004. T. 2. $552 \mathrm{c}$.

24. Хохлов В.А. Ответственность за пользование чужими денежными средствами. Хозяйство и право. 1996. № 8. С. 38-48.

25. Постанова Верховного Суду України від 20 серпня 2013 р. у справі 3-22гc/13. URL: http://www.scourt.gov.ua/clients/vsu/.../ 3-22ге13.doc.

26. Печений О.П. Прострочення виконання договірного зобов'язання : автореф. дис. ... канд. юрид. наук. Харків, 2002. 12 с.

27. Попов Ю. Правовая природа так называемых «процентов годовых». Юридичний журнал. 2002. № 3. С. 54-58.

28. Гуйван П.Д. Темпоральні аспекти виконання грошового зобов'язання та застосування відповідальності за його порушення. Підприємництво, господарство і право. 2014. № 1. С. 3-7.

\section{Information about the author:} Guyvan Petro Dmytrovych, Candidate Juridical Sciences, Honored Lawyer of Ukraine, Professor

Poltava Institute of Business 7, Sinna str., Poltava, 36039, Ukraine 